\title{
NEW INDUSTRIAL BUSINESS MODELS: FROM LINEAR TO CIRCULAR ECONOMY APPROACH
}

\author{
N. Sterev* \\ UNWE-Sofia, Bulgaria
}

\begin{abstract}
In the growth of the Industry 4.0 transformation the economy has become to changed. Thus, not just the economy regulations are fostered but a new business approach has been arisen: the circular / regenerative economy approach. The EC already reacted as it introduced not just updated Sustainable development indices but a new set of indices: circular economy indices.

According to this change of the economic model, the business organizations are fostered to change their business models, especially for the industry. Thus, not just the new regulations have to be introduced to the industrial business model but the total change of the added value of the business as introduction of green technologies or innovations for non-waste production value chains.

Aim of the paper: to identify and to analyze the requirements to the business that foster them to change their linear business model to circular one.

Methods: descriptive analysis of the Bulgarian economy according to circular economy indices; comparative analyses for identification of main differences between linear and circular economies; induction and deduction of the elements of business models.

Results: analysis of the indices of circularity of the Bulgarian economy; analysis of requirements for transition from linear to circular economy; identifying requirements to the business model of a circular economy; systematizing rules / guidelines for transforming the business model of a linear economy into the business model of a circular economy.

Conclusions: The indicators of the circular economy can be considered as a part of the harmonization process in the EU. Avoiding from the responsibilities of the circular economy approach by Bulgarian industry leads to moving away from the EU economies. This requires relevant national policies, measures and instruments to promote the transformation of the business model to circular one.

The paper aims to present the need of industrial business model change as to analyze the starting position of the Bulgarian industry. Thus, the structure of the paper is following: 1. Introduction to Circular economy indices. 2. Definition of Circular economy approach. 3. Analysis of the Circular economy indices change for Bulgaria. 4. Introduction to business model change from linear to circular one. Conclusions.
\end{abstract}

Key words: circular economy, business model, Bulgarian

\section{INTRODUCTION}

Circular economy is fast growing topic nowadays as there is found a desperate need of business and society transformation. According to the business economics' development, the business model not just shifts from Industry 4.0 to Industry 5.0 but the shift is so fast as it has never been before.

Just looking at the industrial changes (Figure 1) we could find how the shift from one technology era to another increases rapidly.

*Correspondence to: Nikolay Sterev, UNWESofia, Bulgaria, Sofia 1700, Studentski grad, 8-mi Decemvri,0898481652,ind.business@unwe.bg
There is a century period between any of first 3 stages of development, less than half century shift between Industry 3.0 and Industry 4.0, and may by a quarter of century for shift to Industry 5.0 .

So, the introduction of the social based technologies from the beginning of 2000s pushes up the change of the business model. Thus, the social impact of business activities as well as the group/mass type of thinking set that the individual prosperity is no longer accepted if the group has to survive. 
The final result is introduction of "circular economy" / "regenerative economy" as an opposite business thinking model controversy to traditional, so called "linear economy".

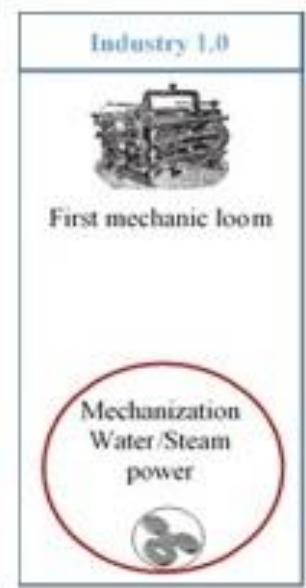

1784

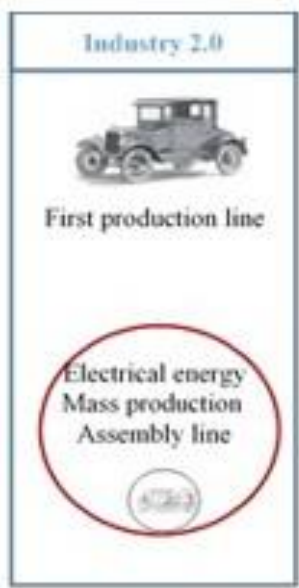

1870

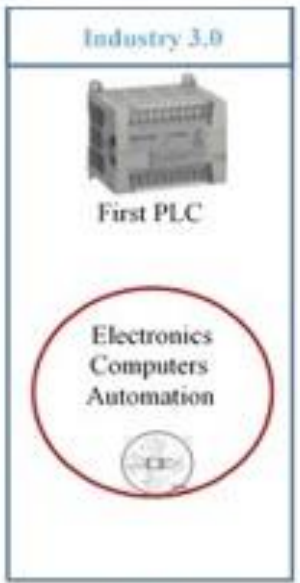

1969

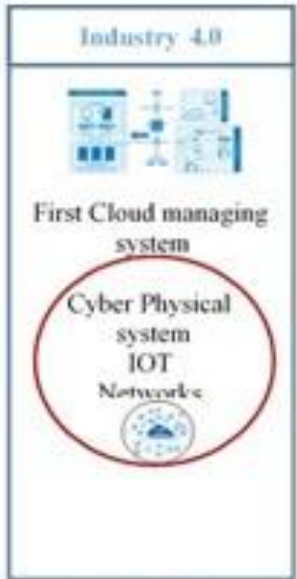

2009

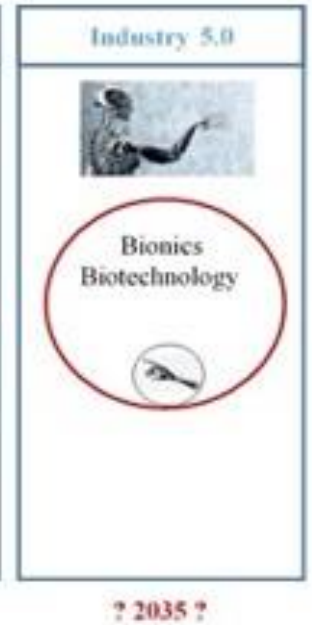

$2035 ?$

Figure 1. Industry Revolution Stages

Source: Modification of T\&A (Taskforce \& Advisor Sàrl), https://www.ta-ad.biz/en/tindutrie-4-0 (1)

\section{INTRODUCTION TO CIRCULAR ECONOMY INDICES}

The explanation of the nature, principles and aims of circular economy (CE) needs to describe the main reasons for its introduction.

From the business economics' position, the last biggest change of economic model is set in the 1960s - 1970s. So called "marketing era" forces the sell and respectively the production of variety of products. As the Industry needs to sell more products it needs more inputs (traditionally the production function covers: materials, labor and capital investments). But the contemporary materials are artificially produced by chemical processes or are naturally based on shrinking areas of those natural materials. And this is the linear model (LE) that is based on "extraction usage - waste production". In addition, the expensive "human capital" become to be replaced by the technology innovations (for example, the mechanization machines in $1780 \mathrm{~s}$

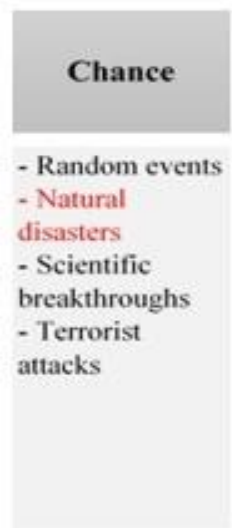

$\begin{aligned} & \text { Firm strategy, } \\ & \text { Structure and } \\ & \text { Revelry }\end{aligned}$
- Company
Strategy
- Structure of the
organization
- Managerial
System
- Intense
competition

via assembly lines in 1870 s to the computerbased machines in 1970s).

The society needs become more and more important from the mid-1990s, when the people received much more free time with the technical and technological inventions. Thus, the business economics' model become to change the "human mode" from single to the group/mass influence. The management model also become to shift as the group techniques become more important: development of business mission; development of Quality Management Systems; development of social influencers. In addition, the "business environmental change" shifts from the single model of competition (2) to the multi-variable competition (3). Some of multi-variable forces that change the "single mode competition" are: natural disasters (chance); natural resources (production factors); environmental / health / social needs of customers (demand factors); added value creation (supporting industries); environmental global and regional policies and regulation (government) (Figure 2).

\begin{tabular}{l} 
Factor \\
Conditions \\
\hline - Natural \\
resources \\
- Human \\
Resources \\
- Capital \\
Resources \\
- Infrastructure \\
- Scientific \\
Knowledge \\
- Technological \\
Innovation
\end{tabular}

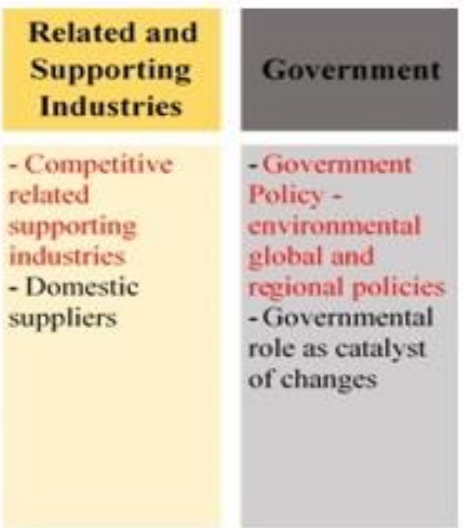

Figure 2. Porter's Diamond Model

Source: Modification of Porter, M.E., 1990, https://www.business-to-you.com/porter-diamond-model/ (4) 
So, not surprisingly the global economists started to talk about environmental protection and the shift from traditional LE to the new, modern CE.

\section{DEFINITION OF CIRCULAR ECONOMY (CE) AND ITS CORE AIMS}

Understanding the shift between LE to CE is based on defining "Circular Economy". The idea of Circular economy is not really new but it has been not accepted till mid-2010s. As the firsw ideas of a Nature-based economic business model has been proposed by ecological economist Kenneth Boulding (5), the real boom of development of his main ideas has come after 2009 as above $70 \%$ of publications on topic $\mathrm{CE}$ were published after 2016 (Figure 3)

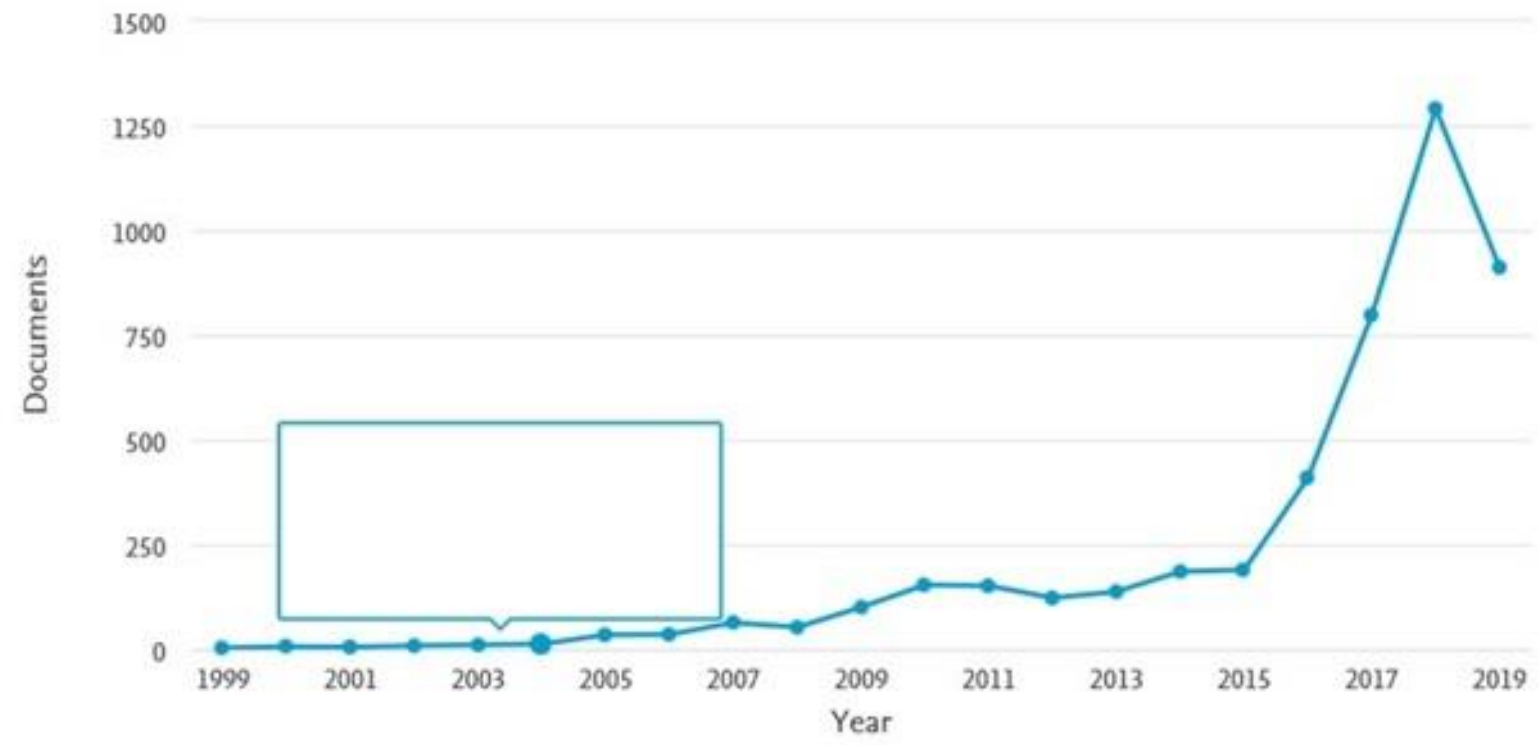

Source: Scopus

Figure 3. Papers on Circular economy

https://www.scopus.com/term/analyzer.uri?sid=992d5d1a1cac2b3f91e7f6912bdcd860\&origin=resultslist\&src=s \&s=TITLE-ABS-KEY\% 28Circular+Economy\%29\&sort=plf-

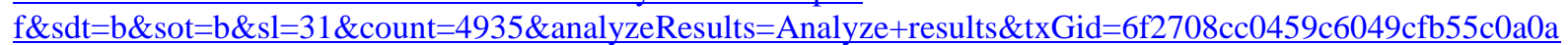
$\underline{\mathrm{cbb} 7 \mathrm{~d}(6)}$

The growth trend of the topic of CE was found by different authors in 2017 (7-8). Thus, the definition and the content of the CE is fully disputable yet. But the problem that almost all authors mentioned is that the current business model is not enough sustainable. So, the CE problems are interesting as for the researchers - economists, ecologists, technical and civil engineers etc., as for the consulting corporations and International institutions.

\section{But what exactly the $\mathrm{CE}$ means and is it opposite to LE?}

Starting with Linear Economy definition. It expresses the classical business model that use natural resources to make different goods and to dispose waste back to the environment. The model "take-make-dispose' pattern" push up extended growth by exploration of more and more natural resources. But this business model was put on conflict with the Global Aims, that are oriented to the community and sustain the life of the Earth. Furthermore, LE has almost reached upper limits of the business growth based on (9-10)

- Increasing volume of waste municipal and industrial;

- Volatility of the price of prime natural resources - the prize forecasts become more and more though, as natural disasters could push up prizes to higher level as for example: petrol prize crises, basic food prize crises etc.

- Concentration of the population in small areas as emerging countries or big cities in developed countries makes the task for sustaining life of the mass people too hard for fulfilling.

Circular Economy is not an opposite approach to the business model but it shifts some main problems of the LE to advantages:

- Increase the cycles of the usage of materials as for the same benefits or for newer ones. This will keep the industrial growth but instead of new natural resources the growth is 
based on cycling use of already at least once used resources;

- Increase the value-chain options as new business networks have to be established. The higher competition in value-chains decreases the volatility of prizes and opens new opportunities;

- Collaboration of high intensive population regions will provide better logistics decisions that means less costs and less waste.

So, CE is not really opposite approach to the LE's business model, but CE provides a new type of collaborative social thinking that is generally important to sustain the human life of the Earth. Some authors that have made review of CE concept, its business models and connection of sustainability and sustainable aims are: Ghisellini et al. (11), Sauvé et al. (12), Murray et al. (13), Geissdoerfer et al. (14), Kirchherr et al. (15), Kalmykova et al. (16) and others.

According to this we could find some basic definitions of $\mathrm{CE}$ could be appointed in division in three groups:

- $\quad \mathrm{CE}$ as economic system, based on the resource approach:

"production and consumption of goods through closed loop material flows that internalize environmental externalities linked to virgin resource extraction and the generation of waste (including pollution)' (17, p. 49) in $(18$, p.4)

According to Pearce \& Turner (19), Sauvé et al. (20), Preston (21) and others, CE represents a different way, in comparison with LE, of the usage of resources. The core idea of these definitions is to reduce waste and pollution by resource efficiency and reduced resource consumption.

- $\mathrm{CE}$ as economic and business approach

"A circular economy describes an economic system that is based on business models which replace the 'end-of-life' concept with reducing, alternatively reusing, recycling and recovering materials in production/distribution and consumption processes, thus operating at the micro level (products, companies, consumers), meso level (eco-industrial parks) and macro level (city, region, nation and beyond), with the aim to accomplish sustainable development, which implies creating environmental quality, economic prosperity and social equity, to the benefit of current and future generations." (22, p.225)
According to Kirchherr et al. (23), CE could not be achieved by the single business, but it needs support of different stakeholders starting from the Governmental support through Related industries and Demand conditions to the Business strategies (Figure 2), The Circular Economic Progress for Stakeholders (CEPS model) is further explained in Taranic et al (24).

\section{- $\quad$ CE as economic business model}

"[CE] an industrial system that is restorative or regenerative by intention and design. It replaces the 'end-of-life' concept with restoration, shifts towards the use of renewable energy, eliminates the use of toxic chemicals, which impair reuse, and aims for the elimination of waste through the superior design of materials, products, systems, and, within this, business models" (25, p. 7) in Geissdoerfer et al. (26, p.759)

According to EMAF (27) and others, CE is a result of Reshape the industrial value-chains as include newer product design, process management and technological innovation. Based on cradle-to-cradle principles (28) the innovation business efforts have to be appointed to the Fifth Industrial Revolution and development of Bio-technologies and Bionical technologies (Figure 1)

Those definitions primary are based on three processes:

- Resource efficiency: the concept means the same business results to be achieved by less number of resources. It is close to the concept of eco-efficiency, where the reduction is combined with replacement of hazardous material with eco-friendlier ones. For example, in the building sector CE approach is used by eco-design of buildings and usage of less $\mathrm{CO} 2$ -intense material.

- Utilization and reuse: the concept explain usage of more and more bio-materials that are not harmful to the Environment. This means not just usage of renewable materials such as renewable energy but to use the waste to give the "next life" of the thrown away materials. For example, the used plastic could be recycling in new products or to be used for production of new energy resources - fuel.

- Consumption shift and sharing using models: the concept explains the reduction of consumption by changing the consumer behaviour through social type of decision making, the need of some products could be reduced as well as the total waste of their production or usage. For example, the 
sharing model is used in automobile consumption where the consumer mind-set is away from the need to own a product (29).

\section{ANALYSIS OF THE CIRCULAR ECONOMY INDICES CHANGE FOR BULGARIA}

According to the given definitions of $\mathrm{CE}$, the level of circularity of the economy could be found by analysis of main indices of the CE.

The basic indices of the circularity if the economy are given by the EU strategic aims and are observed by the European Statistic Office - Eurostat. The indices that are include cover the economic activity in so called $\mathrm{CE}$ sectors: recycling sector, repair and reuse sector and rental and leasing sector.

- The CE economic model indices (code: cei_cie010). Their definition is according the Structural Business Statistics (SBS) framework and cover:

- Gross investment in tangible goods: investment during the reference year in all tangible goods. Included are new and existing tangible capital goods, whether bought from third parties or produced for own use (i.e. capitalised production of tangible capital goods), having a useful life of more than one year including non-produced tangible goods such as land.

$\circ \quad$ Number of persons: the total number of persons who work in the observation unit, i.e. the firm (inclusive of working proprietors, partners working regularly in the unit and unpaid family workers), as well as persons who work outside the unit who belong to it and are paid by it - e.g. sales representatives, delivery personnel, repair and maintenance teams. It excludes manpower supplied to the unit by other enterprises, persons carrying out repair and maintenance work in the enquiry unit on behalf of other enterprises, as well as those on compulsory military service.

- Value added at factor costs: the gross income from operating activities after adjusting for operating subsidies and indirect taxes. It can be calculated as the sum of turnover, capitalized production, other operating income, increases minus decreases of stocks, and deducting the following items: purchases of goods and services, other taxes on products which are linked to turnover but not deductible, duties and taxes linked to production. Value adjustments (such as depreciation) are not subtracted.

- The CE recyclable waste trade (code: cei_srm020): measures the quantities of selected waste categories and by-products that are shipped between the EU Members States (intra-EU) and across the EU borders (extraEU). The indicator includes the following variables:

- Intra EU trade of recyclable raw materials (measured as the Imports from EU countries)

- Imports from non-EU countries and exports to non-EU countries of recyclable raw materials (as regards extra-EU trade).

The indicator is based on International Trade in Goods Statistics (ITGS) published by Eurostat. The scope of the recyclable raw materials is measured in terms of relevant product codes from the Combined Nomenclature used in International Trade in Goods Statistics.

The recycling, repair and reuse and rental and leasing sectors are defined and approximated in terms of economic activity branches of the NACE Rev. 2 classification.

- The CE Recycle index (code: cei_wm011): The indicator measures the share of recycled municipal waste in the total municipal waste generation. Recycling includes material recycling, composting and anaerobic digestion. The ratio is expressed in percent (\%) as both terms are measured in the same unit, namely tonnes.

- The CE waste and eco-efficiency (code: cei_pc031): The indicator measures the waste collected by or on behalf of municipal authorities and disposed of through the waste management system. It consists to a large extent of waste generated by households, though similar wastes from sources such as commerce, offices and public institutions may be included.

These 4 main indices express the level of Circularity of the Economy: Recover - Recycle Reuse.

First of all, the CE approach starts with the Recovery of the waste. It means that the ecoefficiency is optimizing the general waste and follows to its reduction. The Figures for Bulgarian case are given of Figure 4.

The data (Figure 4) shows that the total reduction of the collected generated waste is $29 \%$ from 2000 to 2017. So, instead of increasing the level of collected general waste is reduced. In comparison with other EU countries, Bulgaria is close to the other Balkans countries - Romania, Serbia, Bosna and Herzegovina and etc. And it is opposite to the EU-developed countries: Norway, Germany, Austria, Netherlands and etc., where the eco-efficiency grows from $0 \%$ (Germany) to $22 \%$ (Norway) 


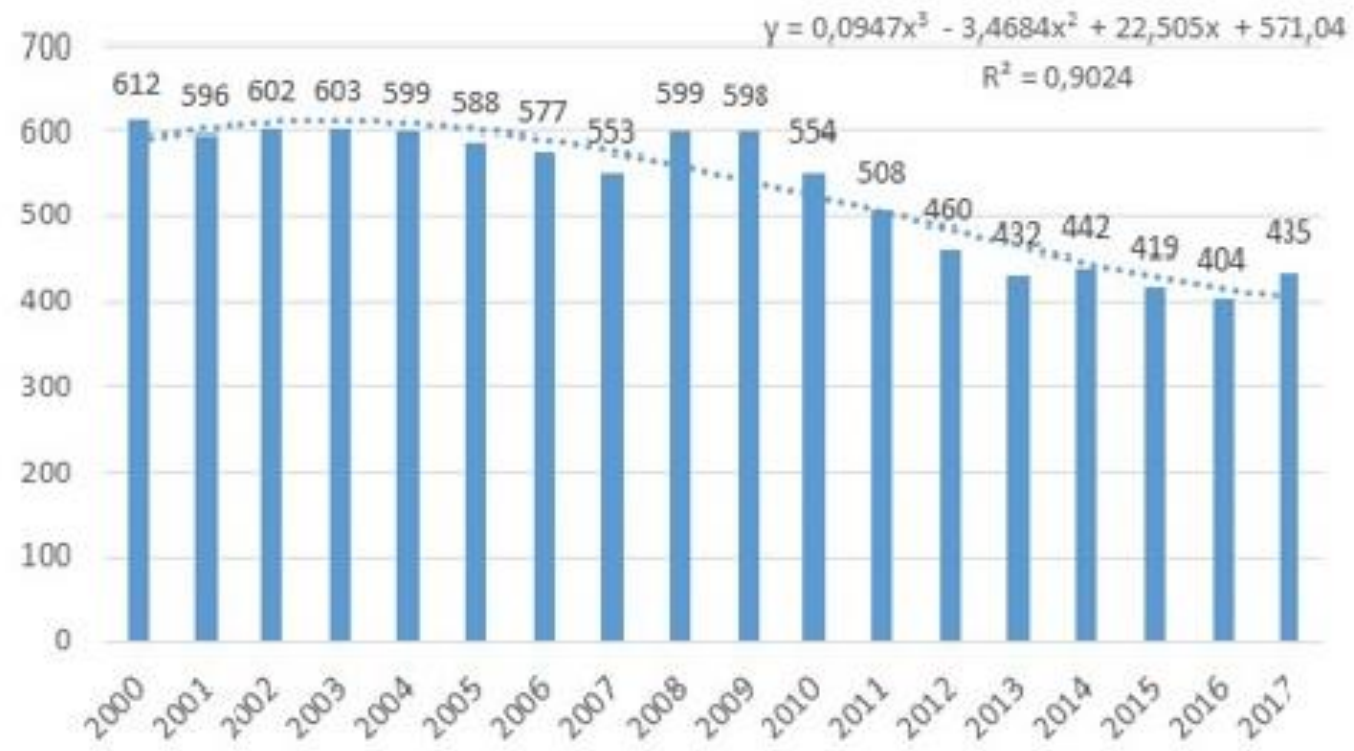

Figure 4. Generation of municipal waste per capita

Source: Eurostat, https://ec.europa.eu/eurostat/(30)

On the second place, the index of recycle waste explain the level of increasing second life of the waste (Figure 5).
Obviously, the index has to grow in the CE approach. The benchmark of the index is the share of recycling in the developed countries. For example: Germany - 68\%, Austria - 58\%, Netherlands $-54 \%$.

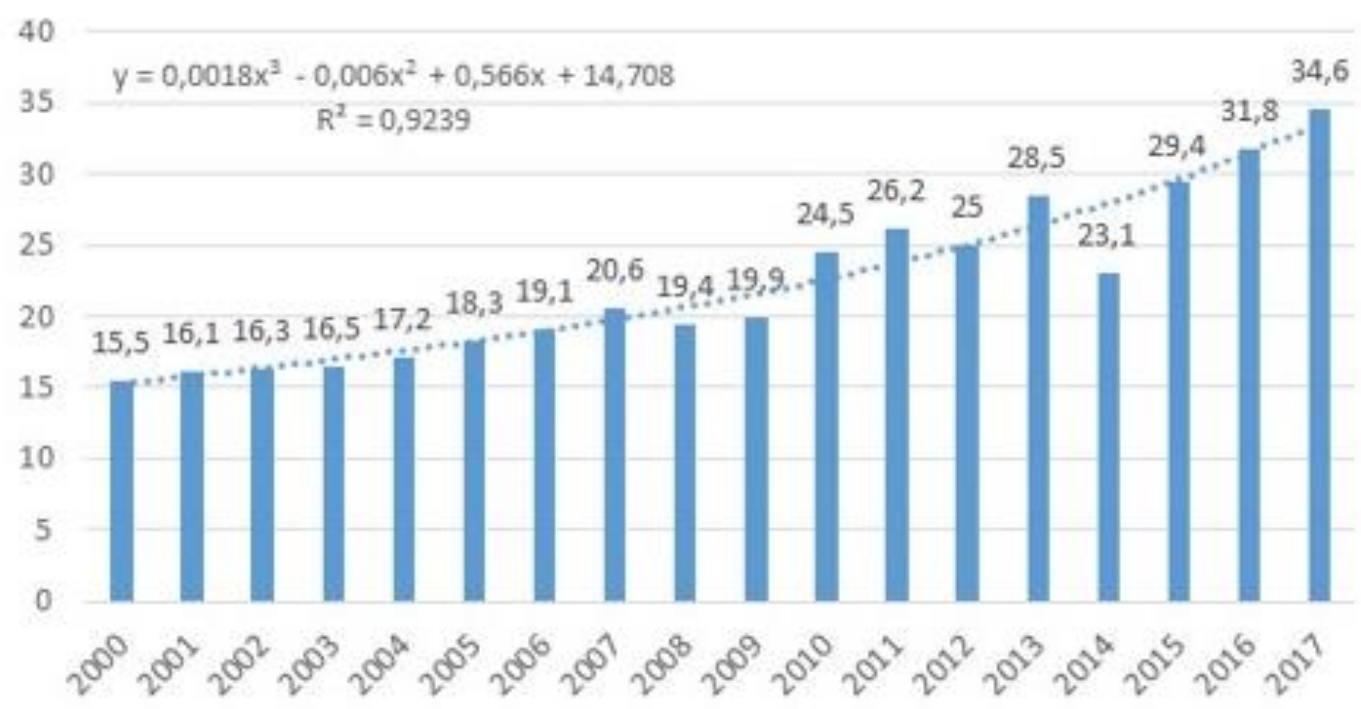

Figure 5. Recycling rate of municipal waste (\%)

Source: Eurostat, https://ec.europa.eu/eurostat/

The data (Figure 5) shows that the recycle rate of the generated waste grows up is more than double from 2000 to 2017. Nevertheless, the recycling rate is almost 2 times less than the Germany and 0.5 times less the EU-average.

On the third place, the trade of the recyclable materials measures the change of the valuechains according to the $\mathrm{CE}$ approach. The growing number of traded recyclable materials is needed (Figure 6)
The data (Figure 6) shows that the number of traded recyclable raw materials in Bulgaria grows up 2.5 times between 2008 and 2016 (from 44.6 thousand tones to 101.1 thousand tones). According to the data Bulgaria is at the EU-middle with 4.5 times more traded recyclable material than Romania, but 6 times less Netherlands and 13 times les Germany. 


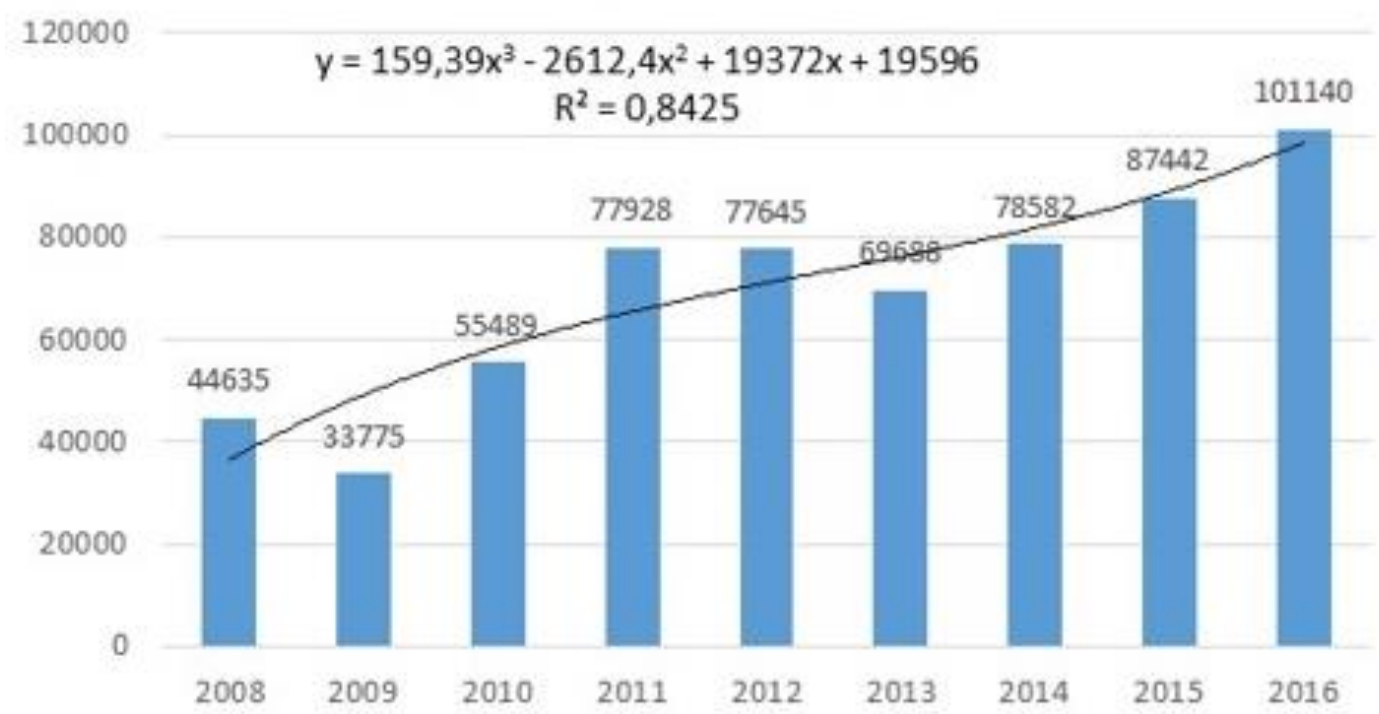

Figure 6. Trade in recyclable raw materials, tones

Source: Eurostat, https://ec.europa.eu/eurostat/

At last, but not least, the total economic change of the CE, measured by the change of value added (Figure 7), Number of employed persons (Figure 8) and Gross investments (Figure 9). The growing figures of any of the sub-indices shows the growing importance of the CE approach on the economy. The benchmark is the developed countries: Germany, Austria, Netherland, Norway and etc.

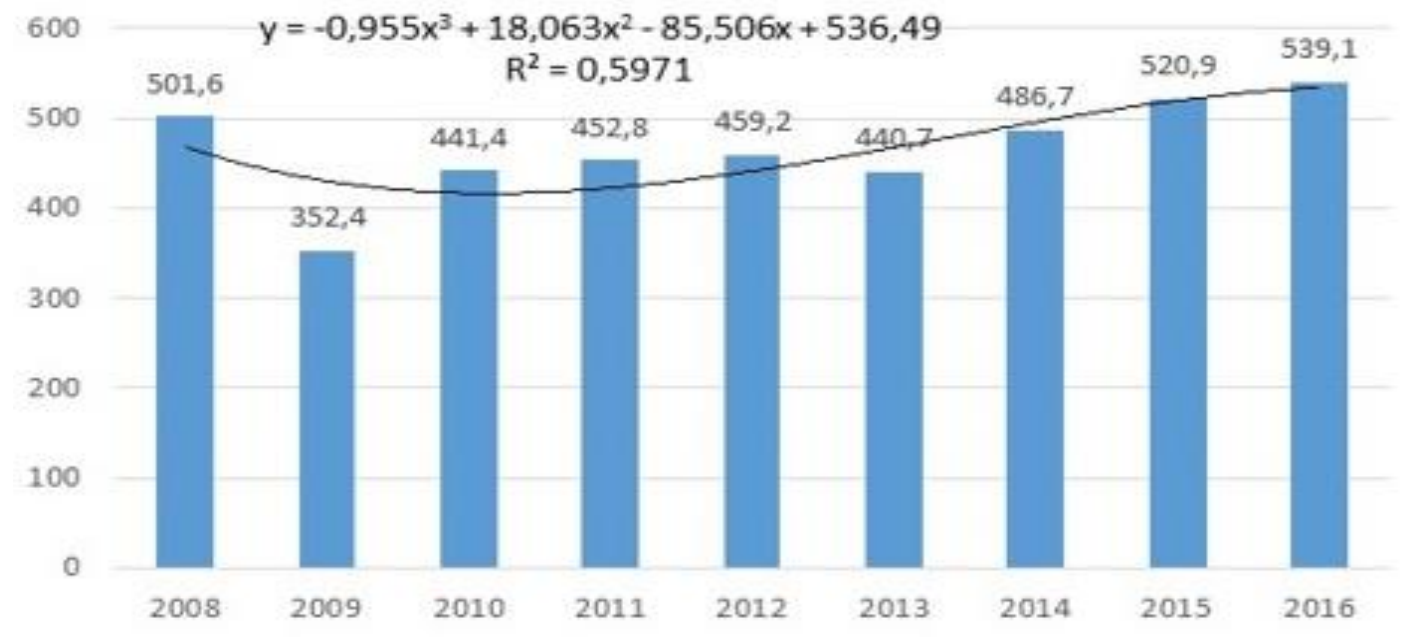

Figure 7. Value added at factor cost of CE sectors (Mio Euro)

Source: Eurostat, https://ec.europa.eu/eurostat/

The data (Figures 7-9) shows that the CE approach is not leading one as the Added value of CE sectors in 2016 is less or equal to number Added value of CE sectors in 2008, as well as the number of employed in CE sectors, in combination with $20 \%$ less gross investments in $\mathrm{CE}$ sectors.

In comparison with the EU - countries: $20 \%$ growth of Added value in Germany and $40 \%$ growth in Austria, and 20\% growth of employed persons in Germany. The gross investments in Germany grows up 30\% for the period.

In summary, Bulgaria is close of acceptance to CE approach to the other Eastern countries, especially on the Balkans. The level of collected general waste is not enough great as well as the rate of recycling the waste is $2-3$ times less than the EU-leading countries. In addition, although increasing volume of trade recyclable raw material, the total added value and investments in the $\mathrm{CE}$ sectors in Bulgaria lack behind. 


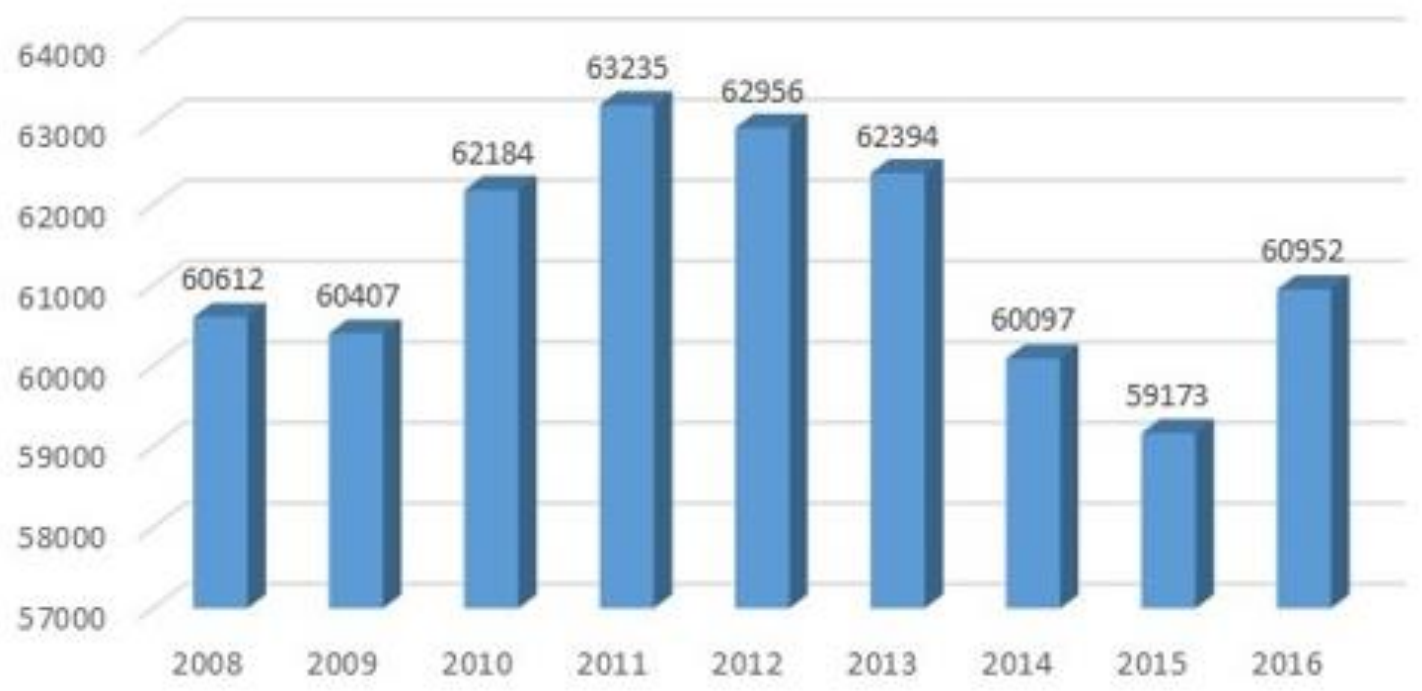

Figure 8. Number of employed in CE sectors

Source: Eurostat, https://ec.europa.eu/eurostat/

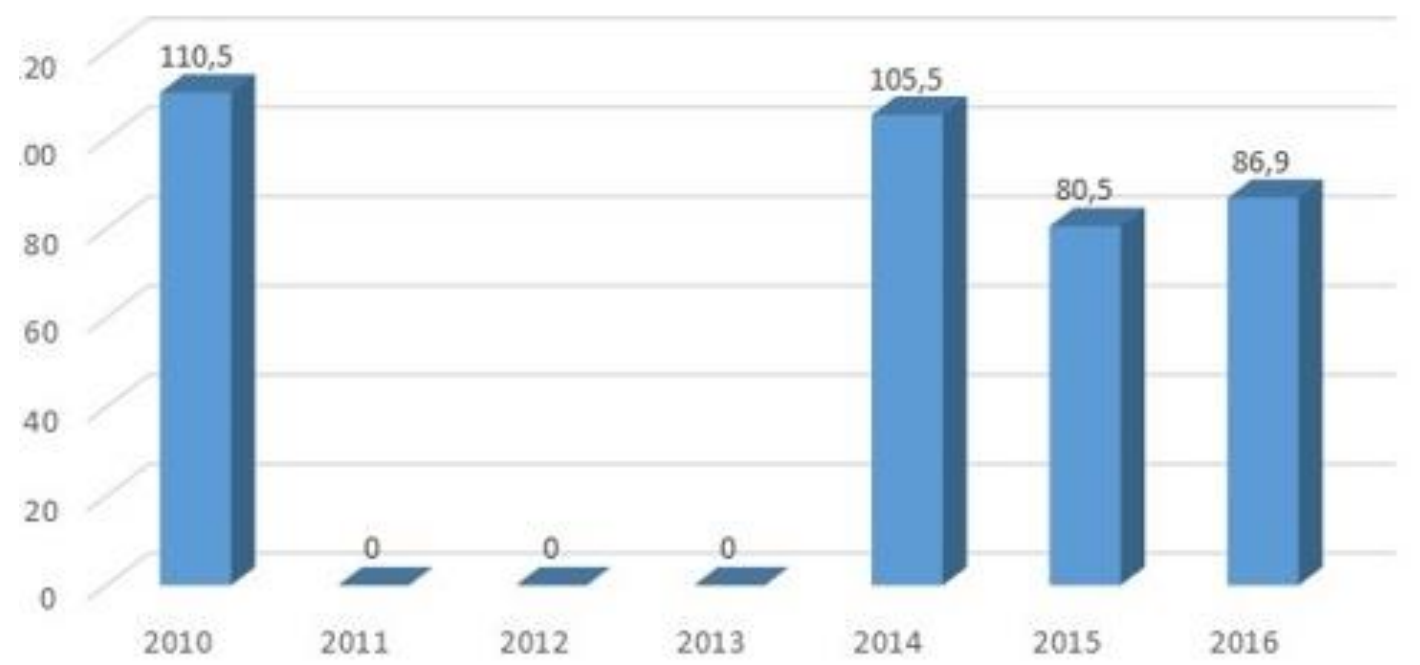

Figure 9. Gross investments in tangible goods in CE sectors (Mio Euro)

Source: Eurostat, https://ec.europa.eu/eurostat/

The leading countries that show a good perspectives of acceptance the CE approach are: Germany, Austria, Netherlands and Norway. So, the good practices for shifting the industrial business model should be used from them. It is not just the Regulation as the Innermotivation to make the change from linear model to the Circular business model.

\section{BUSINESS MODEL CHANGE FROM LINEAR TO CIRCULAR ONE}

Increasing the level of $\mathrm{CE}$ in Bulgaria needs the change not just in business but change of behavior of business Stakeholders. Nevertheless, the CE changes are more smooth if they are done "inside-outside", resp. from the business model to the Business Environment, instead of "outside-inside", resp. from the Governmental restrictions to the Business behavior.

So, the change of the industrial business model based on "inside-outside" approach needs to define not just the Cradle-to-Cradle product design process but to define the whole range of internal $\mathrm{CE}$ business processes.

First of all, the CE shift is based on the Cradleto-Cradle approach (Figure 10) 


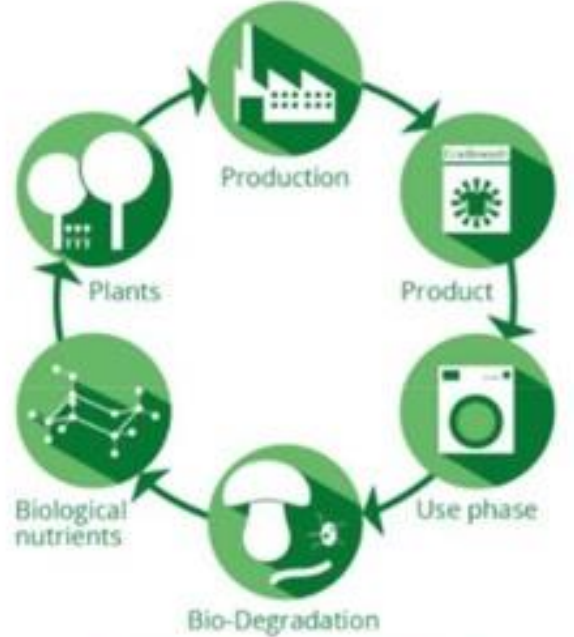

BIOLOGICAL CYCLE

for products for consumption

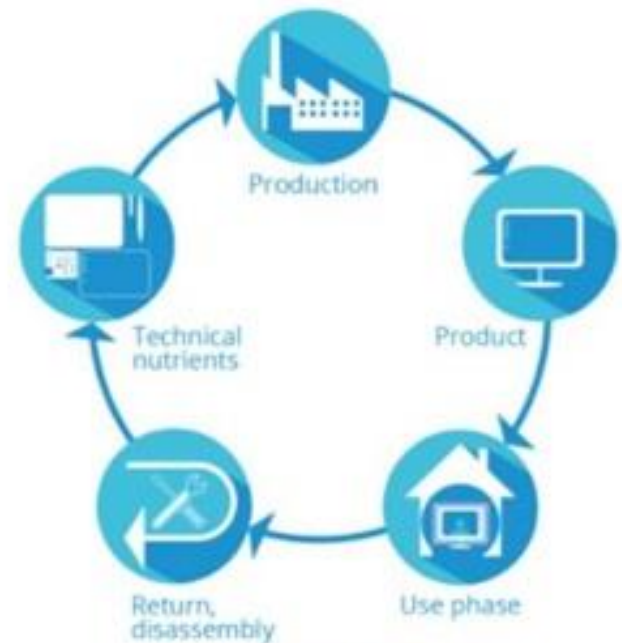

TECHNICAL CYCLE

for products for service

Figure 10. Biological and technical cycles in the Cradle-to-Cradle design

Source: EPEA (2017) (31) in Wautelet (2018) (32)

The first cycle expresses the lifecycle of the user consumption products. So, after the usage stage the used biological products are returned to Nature. The CE approach needs the product design to be eco-friendly one and the used products to be safely returned to the natural environment and to have a positive impact on it if possible. Therefore, such consumption products should be made of biodegradable materials (i.e. natural/plant-based materials) which can become, after use, biological nutrients for living systems and flow in biological cycles.

The second cycle express the lifecycle of artificial industrial products. So, after the usage stage the used technical products should close the loop without wasting the Nature. The CE approach needs the product design to be ecoefficiency one and the used products to be put back in the technical cycle (33, p. 111). Therefore, technical products should be made as high quality, durable and easily remanufacturalable products which have many product life cycles through the combination of reuse and innovation.

Secondly, the CE core business principles that are based on the biological and technical cycles are explained as 9R Concept (Figure 11)

\begin{tabular}{|c|c|c|}
\hline & \\
\hline $\begin{array}{l}\text { Cirqutar } \\
\text { Econosny }\end{array}$ & R0 Refuse & $\begin{array}{l}\text { Make products redundant by abandoning its original } \\
\text { function }\end{array}$ \\
\hline products & Rl Rethink & Make products more intensive (sharing products) \\
\hline & R2 Red & Increase product efficiency or use less natural resources \\
\hline & R3 Reuse & $\begin{array}{l}\text { Reuse discarded products from another users with } \\
\text { oniginal function }\end{array}$ \\
\hline Extend & R4 Repair & $\begin{array}{l}\text { Repair defective products to be used with original } \\
\text { function }\end{array}$ \\
\hline Gifespan of & R5 Refurbish & Restore an old produds \\
\hline products & R6 Remanufacture & $\begin{array}{l}\text { Used discarded products in newproducts with the same } \\
\text { function }\end{array}$ \\
\hline & R7 Repurpose & $\begin{array}{l}\text { Used discarded products in newproducts with different } \\
\text { function }\end{array}$ \\
\hline Usefill & R8 Recycle & Process materials to obtain the same or lower quality \\
\hline $\begin{array}{l}\text { Lineapplication } \\
\text { Econgfimaterials }\end{array}$ & R9 Recover & Incineration of material with energy recovery \\
\hline
\end{tabular}

Figure 11. 9R CE business model framework

Source: adaptation of Potting et al. (2017, p.5) (34) in Kirchherr et al. (2017) 
The main four stages of the increasing circularity of the economy are: Reduce, Reuse, Recycle and Recover. (35)

The Bulgarian case shows increasing the level of Recovery and Recycle, but it's still far away from the level of Recovery and Recycle in the developed countries. The statistical evidences are not sufficient to state that Bulgarian business model shifts form LE to CE and from Recovery and Recycle to change into Reuse and Reduce.

Finally, the Ellen MacArthur Foundation (36) presented a business model how the combine Biological and technical cycles and 9R CE Framework (Figure 12)

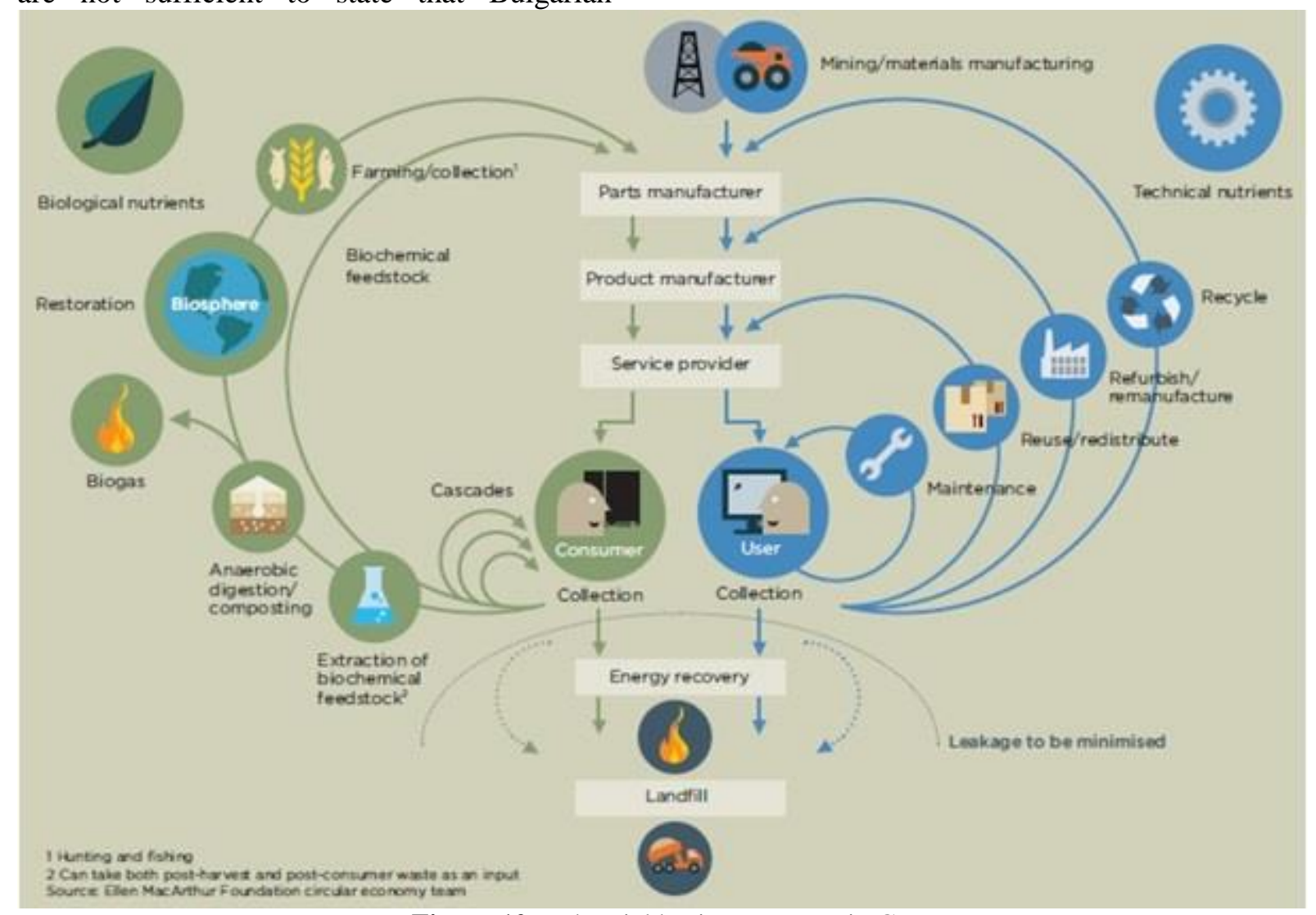

Source: EMAF 2015, p.24

Figure 12. Industrial business system in $\mathrm{CE}$

According to Berg et al. (37), Circular economy business model types are diverse. There are found six different business models:

- Regenerate refers to shifting to renewable energy and materials.

- Share denotes the sharing and recycling economy as well as prolonging the life of products.

- Optimize refers to increased efficiency, waste minimization and utilization of information and communications technology (ICT).

- Loop is defined as closing the technical and biological material cycles.

- Virtualize deals with direct and indirect dematerialization.

- Exchange calls for the utilization of novel materials and technologies.

Different industrial sectors could use different combination of business models as:
- $\quad$ Regenerate, Exchange and Loop;

- $\quad$ Optimize and Loop;

- $\quad$ Share (Product-life extension).

\section{CONCLUSIONS}

The scientists and practitioners are interested of development of the Circular Economy approach. Even though the baseline of the CE thoughts is found in the mid-1960s, the ecological changes and global sustainability aims need a new approach to the business models.

As the rise of the researches of CE is in 20172018, they all discussed not the need of the shift of the "take-make-dispose" to a sustainable business model, but they are focused on the instruments how to make the shift easier and faster.

The shift between business model from the linear (LE) to circular (CE) ones is set as 
priority aim for the Global Forums and European Union. Nevertheless, the speed of this shift is not so fast. As the developed European countries succeeded in the transition from LE to CE, the developing countries, as Bulgaria is, are still stick on the beginning stage.

Bulgaria is close of acceptance to CE approach to the other Eastern countries, especially on the Balkans. The level of collected general waste is not enough great as well as the rate of recycling the waste is 2-3 times less than the EU-leading countries. In addition, although increasing volume of trade recyclable raw material, the total added value and investments in the CE sectors in Bulgaria lack behind.

The leading countries that show a good perspectives of acceptance the CE approach are: Germany, Austria, Netherlands and Norway. So, the good practices for shifting the industrial business model should be used from them. It is not just the Regulation as the Innermotivation to make the change from linear model to the Circular business model.

So, the Bulgarian case shows that the shift from LE to $C E$ is on the first to stages of application of materials: Recover and Recycle. But nevertheless, the growth of Recycled materials, the share of recycled waste is 2 times below the average European level. At the same time, the trade of recycled material, as a result of Reuse and Rethink are more than 7 times less.

The real business model change from LE to CE approaches could be more easily done with promotion of the lessons learnt by the developed countries. And the best practices, that could be multiplied in Bulgaria, cover 3 main CE business strategies models: 1 . Regenerate, Exchange and Loop; 2. Optimize and Loop, and 3. Share (Product-life extension).

\section{REFERENCES}

1. T\&A (Taskforce \& Advisor Sàrl), https://www.ta-ad.biz/en/tindutrie-4-0

2. Porter, M.E., The Five Competitive Forces That Shape Strategy, Harvard Business Review, 2008

3. Porter, M.E., The Competitive Advantage of Nations, Harvard Business Review, 1990

4. Modification of Porter, M.E., 1990, https://www.business-to-you.com/porterdiamond-model/
5. Boulding, K. E., The Economics of the Coming Spaceship Earth, In Jarrett, H. (ed) Environmental quality in a growing economy: Essays from the sixth RFF forum, New York, RFF Press, pp. 3-14, 1966

6. Scopus,https://www.scopus.com/term/analy zer.uri?sid=992d5d1a1 cac2b3f91e7f6912bd cd860\&origin $=$ resultslist $\& \mathrm{src}=\mathrm{s} \& \mathrm{~s}=\mathrm{TITLE}$ -ABS-

KEY\%28Circular+Economy\%29\&sort=plf$\mathrm{f} \& \mathrm{sdt}=\mathrm{b} \&$ sot $=\mathrm{b} \& \mathrm{sl}=31 \&$ count $=4935 \&$ anal yzeResults $=$ Analyze + results $\&$ txGid $=6$ f 270 $8 \mathrm{cc0459c6049cfb55c0a0acbb7d}$

7. Geissdoerfer, M., et al., The circular economy - a new sustainability paradigm. J. Clean. Prod. 143: 757-768, 2017

8. Kirchherr, J., Reike, D., Hekkert, M., Conceptualizing the circular economy: an analysis of 114 definitions. Resources, Conservation and Recycling 127: 221-232, 2017

9. Ellen MacArthur Foundation, Towards the circular economy: Economic business rationale for an accelerated transition, EMAF, London UK, 2013

10.Sariatli, F., Linear Economy Versus Circular Economy: A Comparative And Analyzer, 2017

11.Ghisellini, P., Cialani, C. and Ulgiati, S., A review on circular economy: The expected transition to a balanced interplay of environmental and economic systems, Journal of Cleaner Production, 114: 11-3, 2016

12.Sauvé, S., S. Bernard and P. Sloan, Environmental sciences, sustainable development and circular economy: Alternative concepts for trans-disciplinary research. Environmental Development, 17: 48-56, 2016

13.Murray, A., K. Skene and K. Haynes, The Circular Economy: An interdisciplinary exploration of the concept and its application in a global context. Journal of Business Ethics, 140 (3): 369-380, 2017

14.Geissdoerfer, M., et al., The circular economy - a new sustainability paradigm. J. Clean. Prod. 143: 757-768, 2017

15.Kirchherr, J., Reike, D., Hekkert, M., Conceptualizing the circular economy: an analysis of 114 definitions. Resources. Conservation and Recycling, 127: 221-232, 2017

16.Kalmykova, Y., Madumita, S., Rosado, L., Circular economy - From review of theories and practices to development of implementation tools. Resources, 
Conservation \& Recycling, 135: 190-201, 2018

17.Sauvé, S., Bernard, S., Sloan, P., Environmental sciences, sustainable development and circular economy: Alternative concepts for trans-disciplinary research, Environmental Development, 17:48-56, 2016

18.Rizos V., Tuokko, K., Behrens, A., The Circular Economy: A review of definitions, processes and impacts, Deliverable 2, 2017

19.Pearce, D. W. and Turner, R. K., Economics of natural resources and the environment, Harvester Wheatsheaf, New York, London, 1990

20.Sauvé, S., Bernard, S., Sloan, P., Environmental sciences, sustainable development and circular economy: Alternative concepts for trans-disciplinary research. Environmental Development, 17:48-56, 2016

21.Preston, F., A Global Redesign? Shaping the Circular Economy, Briefing Paper, London: Chatham House, 2012

22.Kirchherr, J., Reike, D., Hekkert, M., Conceptualizing the circular economy: an analysis of 114 definitions. Resources. Conservation and Recycling, 127: 221-232, 2017

23.Kirchherr, J., Reike, D., Hekkert, M., Conceptualizing the circular economy: an analysis of 114 definitions. Resources. Conservation and Recycling, 127: 221-232, 2017

24.Taranic, I., Behrens, A. and Topi, C., Understanding the Circular Economy in Europe, from Resource Efficiency to Sharing Platforms: The CEPS Framework, CEPS Special Report No. 143, 2016, https://www.ceps.eu/wpcontent/uploads/20 16/07/SR\%20No143\%20Circular\%20

Economy_0.pdf

25.Ellen MacArthur Foundation, Towards the circular economy: Economic business rationale for an accelerated transition, EMAF, London UK, 2013

26.Geissdoerfer, M., et al., The circular economy - a new sustainability paradigm. J. Clean. Prod., 143: 757-768, 2017

27.Ellen MacArthur Foundation, Towards the circular economy: Economic business rationale for an accelerated transition, EMAF, London UK, 2013

28.McDonough, W. and Braungart, M., Cradle to cradle: Remaking the way we make things, North Point Press, New York, 2002

29.Bocken, N.M.P. and Short, S.W., Towards a sufficiency-driven business model:
Experiences and opportunities.

Environmental Innovation and Societal

Transitions, 18: 41-61, 2016

30.Eurostat, https://ec.europa.eu/eurostat/

31.EPEA (2017) The Cradle to Cradle $\AA$ design concept - EPEA [Online], EPEA Internationale Umweltforschung $\mathrm{GmbH}$. Available at http://www.epea.com/cradleto-cradle/;

32. Wautelet, Th., The Concept of Circular Economy: its Origins and its Evolution, 2018,

https://www.researchgate.net/publication/3 22555840_The_Concept_of_Circular_Econ omy_its_Origins_and_its_Evolution

33.McDonough, W. and Braungart, M., Cradle to cradle: Remaking the way we make things, North Point Press, New York, 2002

34.Potting, J., et al., Circular Economy: Measuring Innovation in the Product Chain, 2017, Available at. http://www.pbl.nl/sites/default/files/cms/pu blicaties/pbl-2016-circular-economymeasuring-innovation-in-product-chains2544.pdf In Kirchherr, J., Reike, D., Hekkert, M., Conceptualizing the circular economy: an analysis of 114 definitions. Resources. Conservation and Recycling, 127: 221-232, 2017

35.Kirchherr, J., Reike, D., Hekkert, M., Conceptualizing the circular economy: an analysis of 114 definitions. Resources. Conservation and Recycling, 127: 221-232, 2017

36.Ellen MacArthur Foundation, Towards a circular economy: Business rationale for an accelerated tion, 2015. https://www.ellenmacarthurfoundation.org/ assets/downloads/TCE_Ellen-MacArthurFoundation_9-Dec-2015.pdf

37.Berg, A., Antikainen, R., Hartikainen, E., Kauppi, S., Kautto, P., Lazarevic, D., Piesik. S. and Saikku L., Circular Economy for Sustainable Development, REPORTS OF THE FINNISH ENVIRONMENT INSTITUTE 26, 2018, https://helda.helsinki.fi/bitstream/handle/10 138/251516/

SYKEre_26_2018.pdf?sequence=1\&isAllo wed $=\mathrm{y}$

38.Didenko, N. I., Klochkov, Y. S., Djamilia, F., Skripnuk, Ecological Criteria for Comparing Linear and Circular Economies. Resources, 7: 48; 2018, doi:10.3390/resources 7030048 , www.mdpi.com/journal/resources

39. European Commission, Communication on the review of the list of critical raw 
materials for the EU and the implementation of the Raw Materials Initiative, Communication from the Commission to the European Parliament, the Council, the European Economic and Social Committee and the Committee of the Regions, COM (2014) 297 final..

40.European Commission, COM (European Commission) Closing the Loop - An EU Action Plan for the Circular Economy. Communication From the Commission to the European Parliament, The Council, the European Economic and Social Committee and the Committee of the Regions (2015)
41.Korhonena, J., Honkasalob, A., Seppäläc, J., Circular Economy: The Concept and its Limitations. Ecological Economics, 143: 37-46,

2018 , https://www.sciencedirect.com/science/artic le/pii/S0921800916300325\#bb0115

42.Lewandowski, M., Designing the business models for circular economy: towards the conceptual framework. Sustainability, 8(1); 43, 2016

43. Study For Optimization Of Economy For Sustainability. Visegrad Journal on Bioeconomy and Sustainable Development, 1:31-34, 2017 